\title{
ZFP36 wt Allele
}

National Cancer Institute

\section{Source}

National Cancer Institute. ZFP36 wt Allele. NCI Thesaurus. Code C102963.

Human ZFP36 wild-type allele is located in the vicinity of 19q13.1 and is approximately 3 $\mathrm{kb}$ in length. This allele, which encodes tristetraprolin protein, is involved in the regulation of RNA degradation. 